\title{
McDonald v. City of Chicago: Did Justice Thomas Resurrect the Privileges or Immunities Clause from the Dead? (And Did Justice Scalia Kill It Again?) ${ }^{*}$
}

\section{INTRODUCTION}

All persons born or naturalized in the United States, and subject to the jurisdiction thereof, are citizens of the United States and of the State wherein they reside. No State shall make or enforce any law which shall abridge the privileges or immunities of citizens of the United States; nor shall any State deprive any person of life, liberty, or property, without due process of law; nor deny to any person within its jurisdiction the equal protection of the laws. ${ }^{1}$

The Supreme Court recently held in a 5-4 decision that the Second Amendment right to keep and bear arms is "fully applicable to the States" ${ }^{2}$ through the Fourteenth Amendment. ${ }^{3}$ A plurality of the Court agreed that the Due Process Clause of the Fourteenth Amendment is the constitutional vehicle that incorporates the right. ${ }^{4}$ One Justice, however, broke with 137 years of precedent to find "a more straightforward path" to the same conclusion. ${ }^{5}$ Justice Thomas relied on the Privileges or Immunities Clause of the Fourteenth Amendment to enforce the Second Amendment against the States. ${ }^{6}$ This reasoning, though cited as the petitioners' primary argument, ${ }^{7}$ was not given serious consideration by any other opinion in the case. Possibly the most noteworthy aspect of the

* Christian B. Corrigan. J.D. candidate 2012, University of Kansas School of Law; B.A. 2009, University of Pennsylvania. I would like to thank the Kansas Law Review board and staff for their hard work and dedication during the editing process. I would also like to thank the Federalist Society for inspiring my passion for originalism and for helping me to greater understand the founding principles of freedom, federalism, and judicial restraint. Finally, and above all else, I would like to thank my family for their continuous and unwavering support throughout this and all my endeavors. They are the lifeblood of my successes and I am truly grateful for all they have done.

1. U.S. CONST. amend. XIV, § 1 (emphasis added).

2. McDonald v. City of Chicago, 130 S. Ct. 3020, 3026 (plurality opinion).

3. Id. at 3050 .

4. Id.

5. Id. at 3058 (Thomas, J., concurring in part and concurring in the judgment).

6. Id. at 3059 .

7. Id. at 3028 (plurality opinion). 
decision is that Justice Scalia, a self-proclaimed textualist, originalist, ${ }^{8}$ and fierce critic of substantive due process, ${ }^{9}$ acquiesced to using the much-ridiculed doctrine ${ }^{10}$ of substantive due process to apply the Second Amendment to the States. ${ }^{11}$

The Privileges or Immunities Clause presents a unique and important question in constitutional law. Its exact meaning, role, and relevancy are without consensus today. Originalists generally agree that the framers intended to incorporate at least some of the protections guaranteed by the Bill of Rights. ${ }^{12}$ Some originalists would like to see the Privileges or Immunities Clause revived and used to limit the creation of unenumerated rights - others still may believe in premise, but decline to advocate such a radical change in constitutional jurisprudence. ${ }^{13}$

Operating from an originalist perspective of constitutional interpretation-which assumes that the Clause should be interpreted according to what it meant to the public when it was adopted in $1868^{14}$ this Note practically evaluates the future prospects of the Privileges or Immunities Clause in light of the McDonald v. City of Chicago plurality opinion and the concurrence of Justice Thomas. In an originalist's perfect world, the Supreme Court would wipe clean its constitutional slate and use the Privileges or Immunities Clause of the Fourteenth Amendment to enforce the Bill of Rights against the States rather than the Due Process Clause. Fourteenth Amendment jurisprudence as it stands now, however, may permanently preclude incorporation via the Privileges or Immunities Clause.

8. Alan Gura, Ilya Shapiro \& Josh Blackman, The Tell-Tale Privileges or Immunities Clause, in Cato Institute, Cato Supreme Court Review: 2009-2010, at 163, 183 (2010) (citing Hon. Antonin Scalia, Assoc. Justice, U.S. Supreme Court, Address to the Federalist Society National Lawyers Convention (Nov. 22, 2008)).

9. See KEVIn A. RING, SCALIA DisSENTS 304 (2004).

10. That is much ridiculed by originalists. See, e.g., Gura, Shapiro \& Blackman, supra note 8, at 170 ("[T]here was no evidence-none-that the ratifiers of the Fourteenth Amendment understood the Due Process Clause to transmit substantive rights ....”.). "Justice Scalia famously derided substantive due process as an "atrocity' and an act of 'judicial usurpation." Id. (quoting City of Chicago v. Morales, 527 U.S. 41, 85 (1999) (Scalia, J., dissenting)).

11. McDonald, 130 S. Ct. at 3050 (Scalia, J., concurring).

12. Richard L. Aynes, Ink Blot or Not: The Meaning of Privileges and/or Immunities, 11 U. PA. J. CONST. L. 1295, 1309 \& n.71 (2009) (citing RANDY E. BARNETT, CONSTITUTIONAL LAW: CASES IN CONTEXT 292 (2008)).

13. Such pragmatism is seen in Justice Scalia's approach in McDonald. See discussion infra Part IV.B.

14. Robert W. Bennett \& LaWrence B. SOlum, Constitutional Originalism: A DEBATE, at vii (2011). 
In reality, there are three obstacles that stand in the way. The first is stare decisis-redefining federal privileges or immunities would likely require overturning 138 years of precedent going back to the SlaughterHouse Cases. ${ }^{15}$ Second, even Justice Scalia has submitted to the fact that substantive due process now enforces individual rights against the States, therefore making it extremely impractical to switch doctrines of incorporation. ${ }^{16}$ Finally, even if the Court considered abandoning substantive due process, it is extremely wary of doing so without a clear consensus on the full scope and meaning of federal privileges or immunities. ${ }^{17}$

\section{HISTORY OF THE PRIVILEGES OR IMMUNITIES CLAUSE}

\section{A. The Fourteenth Amendment}

Before the ratification of the Fourteenth Amendment, the Bill of Rights applied only to the Federal Government and not to the States. ${ }^{18}$ In the 1833 case of Barron ex rel. Tiernan v. Mayor of Baltimore, "the [Supreme] Court, in an opinion by Chief Justice Marshall, ... firmly rejected the proposition that the first eight Amendments operate as limitations on the States, holding that they apply only to the Federal Government."19

But, after the Civil War, the addition of the Thirteenth, Fourteenth, and Fifteenth Amendments "fundamentally altered our country's federal system." 20 In the immediate aftermath of the Civil War, southern states enacted "black codes" designed "to force blacks into a state of subservience and subjugation." ${ }^{21}$ The laws restricted the civil rights and liberties of former slaves. ${ }^{22}$ In response, Congress enacted "the first

15. See 83 U.S. (16 Wall.) 36 (1873); discussion infra Part II.C.

16. See McDonald, 130 S. Ct. at 3050 (Scalia, J., concurring).

17. See id. at 3030-31 (plurality opinion); id. at 3089 (Stevens, J., dissenting). At oral argument, petitioners' counsel answered a line of questioning regarding the privileges and immunities to be incorporated by the Fourteenth Amendment and admitted that he could not "give a full description of all unenumerated rights that are going to be protected." Transcript of Oral Argument at 61-64, McDonald, 130 S. Ct. 3020 (No. 08-1521).

18. McDonald, 130 S. Ct. at 3028 (plurality opinion) (citing Barron ex rel. Tiernan v. Mayor of Balt., 32 U.S. (7 Pet.) 243 (1833)).

19. Id.

20. Id.

21. Kermit L. Hall, Paul Finkelman \& James W. Ely, JR., American Legal History: CASES AND MATERIALS 262 (3d ed. 2005).

22. Id. 
congressional protection of individual liberty in American history"23: the Civil Rights Act of $1866 .{ }^{24}$ Because "[s]ome members of Congress doubted the constitutionality of the 1866 Civil Rights Act," Congress passed the Fourteenth Amendment. ${ }^{25}$

However, "[d]ebate still rages over the purpose or 'intent' of these amendments." 26 "But, at a minimum, the framers of the [Thirteenth and Fourteenth A]mendments believed they were expanding the Bill of Rights to the states and giving Congress broad plenary power to protect both civil rights and civil liberties ....,27

\section{B. Interpretations of the Privileges or Immunities Clause}

There has been much debate in recent decades over the meaning of "[n]o State shall make or enforce any law which shall abridge the privileges or immunities of citizens of the United States." 28 There are disagreements at virtually every step of the analysis, even among those who consider themselves originalists. ${ }^{29}$ First, there is disagreement about "whether the clause was intended simply to require the states to make their laws apply equally to all their citizens or to mandate a certain substantive content to state law."30 The former interpretation focuses on equality and reads the Clause as a nondiscrimination provision similar to the Privileges and Immunities Clause of Article IV, Section 2 of the Constitution, which prevents States from treating visitors differently than residents. $^{31}$ The latter, substantive interpretation reads the Clause as a mandate for a "substantive package of entitlements" to be guaranteed under state law. ${ }^{32}$

23. Id. at 265 .

24. Id. at 262.

25. Id. at 266. "In 1870, Congress 'reenacted' the 1866 act, on the assumption that the ... Fourteenth... Amendment[] gave additional constitutional authority to the law." Id. Congress went on to pass the Civil Rights Act of 1875, however, after the rights of blacks began to deteriorate in 1873 as Democrats began to regain control of the southern states. Id. at 267. In 1883, the Supreme Court found the Civil Rights Act of 1875 unconstitutional. Id.

26. Id. at 259 .

27. Id.

28. U.S. CONST. amend. XIV, § 1.

29. See Calvin Massey, Privileges or Immunities, in ThE HeRITAge GuIDE to tHE Constitution 390, 390 (Edwin Meese III, David F. Forte \& Matthew Spalding eds., 2005).

30. Id.

31. Id.

32. Id. 
The substantive view itself has two competing interpretations as to the meaning of the privileges or immunities of federal citizenship. ${ }^{33}$ The first interpretation applies the Bill of Rights and every other constitutional guarantee to the States. ${ }^{34}$ The second interpretation views the Clause as applying only the Bill of Rights to the States and nothing more. $^{35}$ This interpretation takes a Lockean view of privileges or immunities by defining them broadly as natural rights given to all people that cannot be taken away by government. ${ }^{36}$ Advocates of these views are generally referred to as "incorporationists" in the context of the interpretation of the Privileges or Immunities Clause. ${ }^{37}$

In addition to various disagreements about the meaning of the clause, there is even disagreement about whether it has any meaning at all. ${ }^{38}$ Judge Bork, an originalist icon, famously described it as nothing more than an "ink blot." 39 Of course, Judge Bork's interpretation is directly at odds with Chief Justice Marshall's statement in Marbury v. Madison that "[i]t cannot be presumed that any clause in the constitution is intended to be without effect."40 Chief Justice Marshall's pronouncement notwithstanding, thanks to an infamous 1873 decision by the Supreme Court in the Slaughter-House Cases, the Privileges or Immunities Clause was virtually dead for over a century until 1999 when the Court invoked it in Saenz v. Roe. ${ }^{41}$

\section{The Slaughter-House Cases}

Slaughter-House is an important part of the debate over the meaning of the Privileges or Immunities Clause. The general consensus is that Justice Miller's majority opinion "rejected any significant role for the Privileges or Immunities Clause in the protection of individual rights generally, and in the incorporation of Bill of Rights freedoms more

37. See Kevin Christopher Newsom, Setting Incorporationism Straight: A Reinterpretation of the Slaughter-House Cases, 109 YALE L.J. 643, 647-49 (2000).

38. Robert H. Bork, The Tempting of America: The Political Seduction of the LaW 166 (1990), quoted in Aynes, supra note 12, at 1300.

39. Id.

40. Marbury v. Madison, 5 U.S. (1 Cranch) 137, 174 (1803).

41. Massey, supra note 29, at 393. 
specifically."42 It has also been maligned as " "one of the most outrageous actions of [the] Supreme Court.",43 Right or wrong, Slaughter-House has been controlling precedent on the Privileges or Immunities Clause for 138 years. ${ }^{44}$

During Reconstruction, the State of Louisiana created the Crescent City Live-Stock Landing and Slaughter-House Company in New Orleans. ${ }^{45}$ The Louisiana Legislature, concerned with sanitary conditions in the community, confined slaughtering to the area owned by Crescent City, effectively creating a monopoly because it forced individual butchers to rent space from the government-owned entity. ${ }^{46} \mathrm{~A}$ group of local butchers challenged the Louisiana law as unconstitutional because it "denied them their right to work and consequently violated . . . the Privileges or Immunities Clause." 47 Louisiana claimed the monopoly was a legitimate regulation under its state police power. ${ }^{48}$

Justice Miller, writing for a 5-4 majority, rejected the butchers' claims by finding that the Privileges or Immunities Clause only protected rights that "owe their existence to the Federal government, its National character, its Constitution, or its laws." ${ }^{49}$ Justice Miller began his opinion by examining the Fourteenth Amendment as a whole, explaining how the drafters designed the Citizenship Clause of Section 1 to overrule Dred Scott v. Sandford ${ }^{50}$ "by making all persons born within the United States and subject to its jurisdiction citizens of the United States." ${ }^{21}$ Justice Miller quickly turned his attention to Section 2, where the controversy began.

42. Newsom, supra note 37 , at $650-51$.

43. Michael J. Perry, We the People: The Fourteenth Amendment and the Supreme COURT 58 (1999) (quoting Charles L. Black, JR., A NeW BirTH OF FrEEDOM: HuMAN Rights, NAMED AND UNNAMED 89 (1997)).

44. See McDonald v. City of Chicago, 130 S. Ct. 3020, 3089 (2010) (Stevens, J., dissenting) (noting that, as of 2010, the Slaughter-House precedent had stood for 137 years); see also Saenz v. Roe, 526 U.S. 489, 503 (1999) (relying on Slaughter-House in interpreting the Fourteenth Amendment's Privileges or Immunities Clause).

45. The Slaughter-House Cases, 83 U.S. (16 Wall.) 36, 38 (1873).

46. Id. at 38-43, 57, 62-63, 87.

47. Newsom, supra note 37, at 651 (citing The Slaughter-House Cases, 21 L. Ed. 395, 396-99 (1873)).

48. Slaughter-House, 83 U.S. (16 Wall.) at 87.

49. Id. at 79, quoted in McDonald, 130 S. Ct. at 3022 (plurality opinion).

50. 60 U.S. (19 How.) 393 (1857), superseded by constitutional amendment, U.S. Const. amend. XIV.

51. Slaughter-House, 83 U.S. (16 Wall.) at 73. 
First, Justice Miller pointed out the sharp distinction between citizenship of the United States and citizenship of the states as "clearly recognized and established." 52 Justice Miller then declared that the Constitution only protects the privileges or immunities of federal citizenship and that any rights left to be protected by the States were out of reach of the Fourteenth Amendment. ${ }^{53}$ Before defining federal privileges or immunities, however, Justice Miller-using Justice Washington's list from Corfield $v$. Coryell ${ }^{54}$-first defined the state privileges or immunities guaranteed by Article IV, Section 2:

Its sole purpose was to declare to the several States, that whatever those rights, as you grant or establish them to your own citizens, or as you limit or qualify, or impose restrictions on their exercise, the same, neither more nor less, shall be the measure of the rights of citizens of other States within your jurisdiction. ${ }^{55}$

Under this interpretation, Article IV, Section 2 was essentially a nondiscrimination clause that prevented a State from treating visitors differently under the law than it did its own citizens.

So, then, what exactly are federal privileges and immunities? Justice Miller declined to explicitly rule on this question, and the Court "excused [itself] from defining the privileges and immunities of citizens of the United States which no state can abridge, until some case involving those privileges may make it necessary to do so."56 Justice Miller did, however, give an idea of what rights might constitute privileges or immunities. ${ }^{57}$ First, he cited the "very few express limitations which the Federal Constitution imposed upon the States-such, for instance, as the prohibition against ex post facto laws, bills of attainder, and laws impairing the obligation of contracts." 58 Second, seemingly anticipating the argument that his list of federal privileges and immunities was too narrow, Justice Miller listed several other rights, such as the rights

to come to the seat of government to assert any claim he may have upon that government, to transact any business he may have with it, to

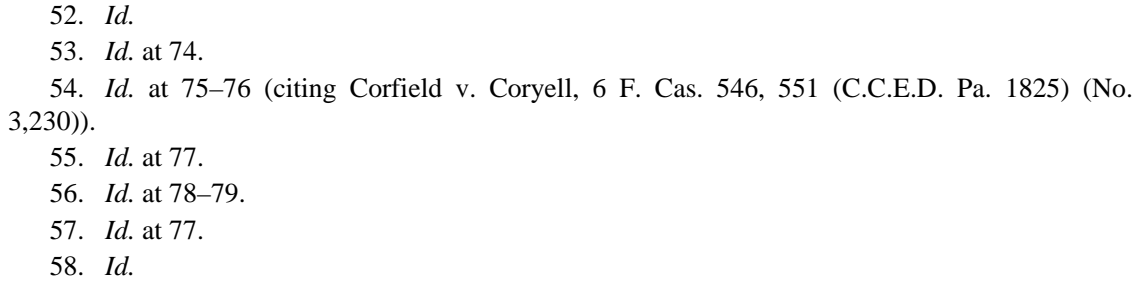


seek its protection, to share its offices, to engage in administering its functions. [A citizen] has the right of free access to its seaports, through which all operations of foreign commerce are conducted, to the subtreasuries, land offices, and courts of justice in the several States. ${ }^{59}$

He also mentioned the right "to demand the care and protection of the Federal government over his life, liberty, and property when on the high seas or within the jurisdiction of a foreign government," "the privilege of the writ of habeas corpus," the "right to use the navigable waters of the United States," and "all rights secured to our citizens by treaties with foreign nations." $" 60$

Most notably, Justice Miller mentioned the "right to peaceably assemble and petition for redress of grievances," ${ }^{\prime \prime}$ a line which parallels some First Amendment protections. ${ }^{62}$ This is significant because it arguably left the door open to interpreting Slaughter-House as incorporating at least some of the Bill of Rights against the States ${ }^{63}$ because the plaintiffs did not actually bring any claims under the Bill of Rights, ${ }^{64}$ and the Court did not explicitly deny incorporation. ${ }^{65}$ Justice Miller did inquire, however, whether the Privileges or Immunities Clause "transfer[red] the security and protection of all the [aforementioned] civil rights ... from the States to the Federal government."66 To this question, he replied that "no such results were intended by the Congress which proposed these amendments, nor by the legislatures of the States which ratified them." 67

Regardless of Justice Miller's intent, subsequent Supreme Court cases closed any opening left by him in Slaughter-House. ${ }^{68}$ As this Note will discuss later, Justice Miller's inclusion of some First Amendment rights in his list is an important point to consider as incorporationists

59. Id. at 79 (alteration in original) (quoting Crandell v. Nevada, 73 U.S. (6 Wall.) 35, 44 (1868)) (internal quotation marks omitted).

60. Id.

61. Id. at 79 .

62. See U.S. CONST. amend. I.

63. See McDonald v. City of Chicago, 130 S. Ct. 3020, 3060 (2010) (Thomas, J., concurring in part and concurring in the judgment).

64. See Newsom, supra note 37 , at 658 .

65. See id. at 666 .

66. Slaughter-House, 83 U.S. (16 Wall.) at 77.

67. Id. at 78 .

68. See McDonald, 130 S. Ct. at 3060 (Thomas, J., concurring in part and concurring in the judgment) (noting the more narrow interpretation of the Privileges or Immunities Clause in the aftermath of Slaughter-House). 
grapple with the necessity of overruling Slaughter-House. In the last decade, scholars have revisited Justice Miller's opinion and concluded that it is friendlier to incorporation than once thought-arguing that it simply fell victim to a series of bad Supreme Court decisions after it was

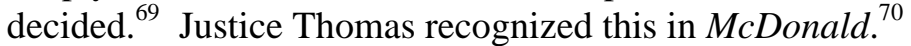

There are a variety of theories on the method to Justice Miller's reasoning. The conventional wisdom has been that he restricted the Privileges or Immunities Clause because the only alternative was to open a Pandora's Box of new legal rights. ${ }^{71}$ Others argue that Justice Miller was primarily worried about a major shift in the balance between state and federal rights based on his concern that the Supreme Court would effectively become the "sperpetual censor" of the state legislatures. ${ }^{72}$ Originalists point out the irony of such concern, given that the method ultimately chosen to enforce the Bill of Rights against the Statessubstantive due process and its kaleidoscope of rights-is subject to exactly that criticism.

\section{Saenz v. Roe}

The next time the Court seriously dealt with the Privileges or Immunities Clause came in the 1999 case of Saenz v. Roe. ${ }^{73}$ California passed a law limiting welfare benefits for new residents of the state. ${ }^{74}$ In order to prevent people from moving to California for larger welfare checks, the statute limited new residents to receiving the same amount of

69. E.g., Newsom, supra note 37, at 649 (stating that "[n]ot once in [Slaughter-House] did the Court seriously suggest... that the Privileges or Immunities Clause did not incorporate Bill of Rights Freedoms" and that "it suggests that core Bill of Rights freedoms are among the 'privileges [and] immunities of citizens of the United States' protected by the Fourteenth Amendment." (third alteration in original) (quoting U.S. CONST. amend. XIV, § 1)).

70. 130 S. Ct. at 3060 (Thomas, J., concurring in part and concurring in the judgment); see infra text accompanying notes 141-43.

71. Newsom, supra note 37, at 666 (citing Louis Lusky, By WhAt Right? A COMMENTARY ON THE SUPREME COURT’S POWER TO REVISE THE CONSTITUTION 199 (1975)).

72. William J. Rich, Taking "Privileges or Immunities" Seriously: A Call to Expand the Constitutional Canon, 87 MiNN. L. REV. 153, 177 (2002) (quoting Slaughter-House, 83 U.S. (16 Wall.) at 78); Richard A. Epstein, Of Citizens and Persons: Reconstructing the Privileges or Immunities Clause of the Fourteenth Amendment, 1 N.Y.U. J.L. \& LiBERTY 334, 337 (2005) (same).

73. 526 U.S. 489, 511 (1999) (Rehnquist, C.J., dissenting) ("The Court today breathes new life into the previously dormant Privileges or Immunities Clause of the Fourteenth Amendment-a Clause relied upon by this Court in only one other decision ....”).

74. Id. at 492 (majority opinion). 
welfare benefits they would have received in their previous state of residence for a period of one year. ${ }^{75}$

Finding an unenumerated right to travel in the Constitution, ${ }^{76}$ Justice Stevens, writing for the majority, struck down the statute as a violation of the Privileges or Immunities Clause of the Fourteenth Amendment because it infringed on citizens' "right to choose to be citizens 'of the State wherein they reside." "77 This right to travel had three components: the right to enter one state and leave another; "the right to be treated as a welcome visitor rather than an unfriendly alien"; and, for those who want to be permanent residents, the right to be treated equally to native-born citizens. $^{78}$ The last right was the principal right violated by the State of California. ${ }^{79}$ Supporting this proposition, Justice Stevens cited the only real existing precedent on the Privileges or Immunities ClauseSlaughter-House. ${ }^{80}$ While acknowledging the controversial nature of Slaughter-House, he asserted that "it has always been common ground that this Clause protects the third component of the right to travel." ${ }^{81} \mathrm{He}$ looked to both Justice Miller's statement in Slaughter-House that any federal citizen can "'become a citizen of any State of the Union by a bona fide residence therein, with the same rights as other citizens of that State,"82 and Justice Bradley's dissent that "used even stronger language to make the same point." 83 For Justice Stevens, the Privileges or Immunities Clause was essentially a nondiscrimination provision protecting the right to migrate and the right to travel. ${ }^{84}$ Justice Thomas and Chief Justice Rehnquist both wrote dissenting opinions. ${ }^{85}$

Although obviously not shy about invoking the Privileges or Immunities Clause, given McDonald, Justice Thomas did not see Saenz as the proper case for its resurrection. ${ }^{86}$ Since the case only involved

75. Id.

76. Id. at 498 ("The word 'travel' is not found in the text of the Constitution. Yet the 'constitutional right to travel from one State to another' is firmly embedded in our jurisprudence." (quoting United States v. Guest, 383 U.S. 745, 757 (1966))).

77. See id. at 510-11 (quoting U.S. ConsT. amend. XIV, § 1).

78. Id. at 500 .

79. Id. at 502 .

80. Id. at 503 .

81. Id.

82. Id. (quoting The Slaughter-House Cases, 83 U.S. (16 Wall.) 36, 80 (1873)).

83. Id. (citing Slaughter-House, 83 U.S. (16 Wall.) at 112-13 (Bradley, J., dissenting)).

84. Tim A. Lemper, The Promise and Perils of "Privileges or Immunities": Saenz v. Roe, 119 S. Ct. 1518 (1999), 23 HARV. J.L. \& PUB. POL’Y 295, 304 (2000).

85. See Saenz, 526 U.S. at 511 (Rehnquist, C.J., dissenting); id. at 521 (Thomas, J., dissenting).

86. See id. at 527-28 (Thomas, J., dissenting) ("I would be open to reevaluating [the Privileges 
benefits established by positive law, and not fundamental rights, only the Equal Protection Clause could possibly be relevant. ${ }^{87}$ To Justice Thomas, the Saenz majority "attribute[d] a meaning to the Privileges or Immunities Clause that likely was unintended when the Fourteenth Amendment was enacted and ratified." ${ }^{88}$ Because the Saenz majority failed to ascertain the original meaning of the Privileges or Immunities Clause, the Slaughter-House opinions and the majority's consensus on the right to travel were irrelevant to an analysis under the Privileges or Immunities Clause. ${ }^{89}$

Justice Thomas chastised Justice Stevens's invocation of the Privileges or Immunities Clause as "yet another convenient tool for inventing new rights, limited solely by the "predilections of those who happen at the time to be Members of this Court." "90 Justice Thomas believed that Justice Washington's 1825 opinion in Corfield v. Coryell defined "privileges" and "immunities" according to their historical understanding - only those "fundamental rights that belong to all citizens of the United States." "91 The majority's use of Slaughter-House "fail[ed] to address its historical underpinnings or its place in ... constitutional jurisprudence." $^{\text {,2 }}$ Justice Scalia, along with Justices Kennedy and O'Connor, silently joined the majority in a 7-2 decision. ${ }^{93}$ Over a decade later, Justice Thomas found a more proper opportunity to invoke the Privileges or Immunities Clause—and he seized it. ${ }^{94}$

\section{MCDONALD V. CITY OF CHICAGO}

In the 2010 case of McDonald v. City of Chicago, a group of petitioners used the Privileges or Immunities Clause of the Fourteenth Amendment to argue that the rights guaranteed under the Second Amendment should apply to the States. ${ }^{95}$ Despite ruling for the

or Immunities Clause's] meaning in an appropriate case.”).

87. See id. at 526-28; see also Lemper, supra note 84, at 308.

88. Saenz, 526 U.S. at 521 (Thomas, J., dissenting).

89. See id. at 522, 527 (noting the majority's failure to examine the Clause's original meaning and that Slaughter-House had "sapped the Clause of any meaning").

90. Id. at 528 (quoting Moore v. City of E. Cleveland, 431 U.S. 494, 502 (1977)).

91. Id. at 525-26 (citing Corfield v. Coryell, 6 F. Cas. 546, 552 (C.C.E.D. Pa. 1825) (No. $3,230)$ ).

92. Id. at 527.

93. Id. at 491 (majority opinion).

94. See infra Part III.B.

95. McDonald v. City of Chicago, 130 S. Ct. 3020, 3028 (2010) (plurality opinion). 
petitioners, the Court chose not to use the Privileges or Immunities Clause-opting instead for the more conventional route through substantive due process. ${ }^{96}$ Justice Thomas's powerful concurring opinion, however, embraced the petitioners' argument and supported the enforcement of the Second Amendment against the States via the Privileges or Immunities Clause. ${ }^{97}$

The petitioner-plaintiffs in McDonald challenged gun-control laws in Chicago and Oak Park, Illinois that banned handgun possession by private citizens. ${ }^{98}$ They claimed that these restrictions violated their Second Amendment right to keep and bear arms as extended in the Court's 2008 decision in District of Columbia v. Heller. ${ }^{99}$ They argued that the Fourteenth Amendment should enforce the Second Amendment against the States-primarily under the Privileges or Immunities Clause and secondarily under the Due Process Clause. ${ }^{100}$ The petitioners asserted that the Court should reject the Slaughter-House interpretation of the Privileges or Immunities Clause as overly narrow. ${ }^{101}$ The respondents, in addition to arguing that the right to keep and bear arms was not fundamental enough to be incorporated via the Due Process Clause, ${ }^{102}$ argued that Section 1 of the Fourteenth Amendment was also merely a nondiscrimination rule, designed to protect the rights of former slaves after the Civil War. ${ }^{103}$

\section{A. Justice Alito’s Plurality Opinion}

1. Applying via the Privileges or Immunities Clause

While the Court did not explicitly reject the argument based on the Privileges or Immunities Clause, it found no reason to revisit SlaughterHouse and decided to adhere to decades of precedent by applying the Due Process Clause to Fourteenth Amendment claims of State infringement. ${ }^{104}$ Justice Alito opened the plurality opinion by addressing

\footnotetext{
96. Id. at $3030-31$.

97. Id. at 3059 (Thomas, J., concurring in part and concurring in the judgment).

98. Id. at 3027 (plurality opinion).

99. Id.

100. Id. at 3028 .

101. Petitioners' Brief at 42-65, McDonald, 130 S. Ct. 3020 (No. 08-1521).

102. Brief for Respondents City of Chicago and Village of Oak Park at 7, 64, McDonald, $130 \mathrm{~S}$. Ct. 3020 (No. 08-1521).

103. Id. at 42-81.

104. McDonald, 130 S. Ct. at 3030-31 (plurality opinion).
} 
the issue as the petitioners hoped he would, by discussing the Barron aftermath and the need for some vehicle to incorporate the Bill of Rights against the States - the Privileges or Immunities Clause. ${ }^{105}$ Naturally, his analysis started with the Fourteenth Amendment and, of course, Slaughter-House. ${ }^{106}$ He discussed Slaughter-House's majority opinion as well as the dissents of Justices Field, Swayne, and Bradley. ${ }^{107}$ He then aptly stated that "[t]oday, many legal scholars dispute the correctness of the narrow Slaughter-House interpretation," but gave no further discussion of the case. ${ }^{108}$ He then mentioned three nineteenth century cases-United States v. Cruikshank, ${ }^{109}$ Presser v. Illinois, ${ }^{110}$ and Miller v. Texas, ${ }^{111}$ which held that the Second Amendment applied only to the Federal Government-and the petitioners' argument for overturning those cases and Slaughter-House. ${ }^{112}$ Justice Alito did not discuss these cases as they related to privileges or immunities. ${ }^{113}$

Justice Alito declined to overturn Slaughter-House and noted that the petitioners could not identify the full scope of the Privileges or Immunities Clause nor was there consensus on the issue among the scholars who believe Slaughter-House was incorrectly decided. ${ }^{114}$ There was no real need to reconsider the interpretation of the Privileges or Immunities Clause in this case because "[f]or many decades, the question of the rights protected by the Fourteenth Amendment against state infringement has been analyzed under the Due Process Clause of that Amendment and not under the Privileges or Immunities Clause.”115

In his dissent, Justice Stevens agreed with the plurality's refusal to overturn Slaughter-House and its decision to adjudicate the case under the Due Process Clause. ${ }^{116}$ Like Justice Alito, he was hesitant to overturn 137 years of precedent. ${ }^{117}$ Justice Stevens noted that "[t]he

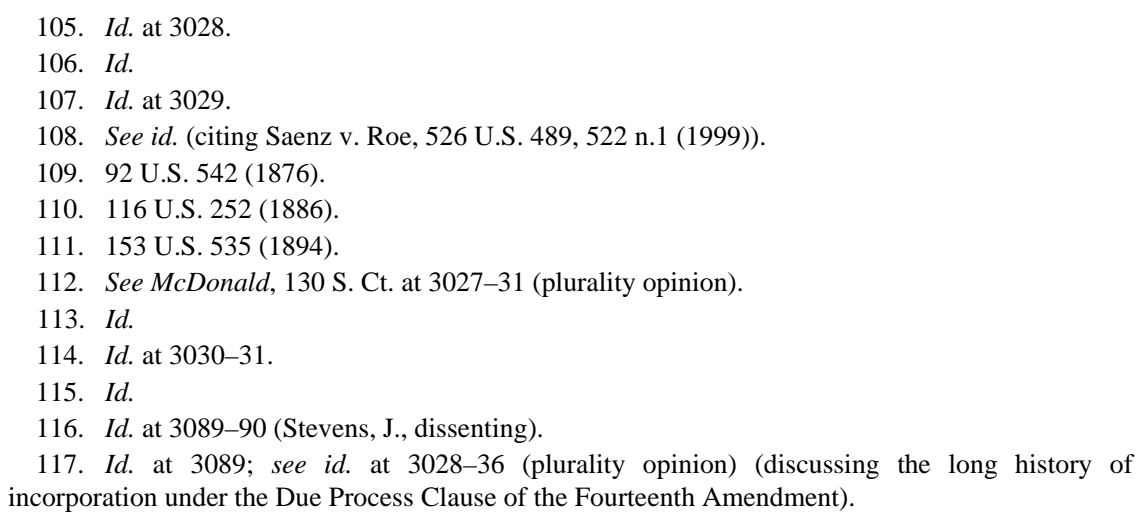


burden is severe for those who seek radical change in such an established body of constitutional doctrine."118 Though he admitted that the petitioners amassed "impressive" evidence supporting their interpretation of the Privileges or Immunities Clause, he argued that "the original meaning of the Clause is not as clear as they suggest."119

\section{Incorporation via the Due Process Clause}

Justice Alito instead used the existing precedent under the Due Process Clause of the Fourteenth Amendment to incorporate the Second Amendment against the States. ${ }^{120}$ First, he rejected the late-nineteenth century precedent of Cruikshank, Presser, and Miller as inapplicable because they preceded the modern jurisprudence on the issue. ${ }^{121}$ They were irrelevant because they did not "'engage[] in the sort of Fourteenth Amendment inquiry required by ... later cases.,"122

Under the Due Process Clause, the Court has incorporated most of the protections of the first eight amendments against the States, but not all. ${ }^{123}$ To determine whether a particular protection in the Bill of Rights applies to the States, Justice Alito saw Duncan $v$. Louisiana ${ }^{124}$ and Washington v. Glucksberg ${ }^{125}$ as the controlling precedent. ${ }^{126}$ The Duncan test asked "whether a particular Bill of Rights guarantee is fundamental to our scheme of ordered liberty and system of justice.”127 The more recent Glucksberg test asked, in a similar context, whether the right is "deeply rooted in this Nation's history and tradition." 128 For Justice Alito and the plurality, the Second Amendment right of individual self-defense satisfied those tests. ${ }^{129}$

The 2008 District of Columbia v. Heller decision made this an easy determination for Justice Alito. ${ }^{130}$ The Heller decision, written by Justice

\footnotetext{
118. Id. at 3089 (Stevens, J., dissenting).

119. Id. at 3089 \& n.2 (gathering sources that illustrate the division on this topic).

120. Id. at 3050 (plurality opinion).

121. Id. at 3031.

122. Id. at 3031 (quoting District of Columbia v. Heller, 554 U.S. 570, 620 n.23 (2008)).

123. Id. at 3034-35. This is commonly referred to as "selective incorporation." Id. at 3034.

124. 391 U.S. 145 (1968).

125. 521 U.S. 702 (1997)

126. McDonald, 130 S. Ct. at 3034, 3036 (plurality opinion).

127. Id. at 3034 (citing Duncan, 391 U.S. at 149).

128. Glucksberg, 521 U.S. at 721, quoted in McDonald, 130 S. Ct. at 3036 (plurality opinion).

129. McDonald, $130 \mathrm{~S}$. Ct. at 3036-38 (plurality opinion).

130. Id. at 3036.
} 
Scalia, struck down a District of Columbia law banning handgun possession in the home. ${ }^{131}$ The Court held that the D.C. law infringed upon a Second Amendment right to individual self-defense, which was "a basic right, recognized by many legal systems from ancient times to the present day." 132 Specifically, the Court noted that "individual selfdefense is 'the central component' of the Second Amendment right."133 Thus, under Heller, the Second Amendment requires that "citizens must be permitted 'to use [handguns] for the core lawful purpose of selfdefense'” in federal enclaves such as Washington, D.C. ${ }^{134}$

In deciding whether this federal right should apply to the States, Justice Alito noted how Heller traced the origin of the Second Amendment back to the 1689 English Bill of Rights. ${ }^{135}$ American colonists enjoyed the right to keep and bear arms, and the Framers of the Constitution during the 1788 ratification debates considered it a fundamental right. ${ }^{136}$ Applying the Heller decision to the Glucksberg test, Justice Alito wrote, "Heller makes it clear that this right is 'deeply rooted in this Nation's history and tradition.",137

Finally, Justice Alito argued in McDonald that it was the express intent of the Framers of the Fourteenth Amendment to protect Second Amendment rights against State infringement. ${ }^{138}$ He pointed to the debates of the thirty-ninth Congress in which sponsors of the Fourteenth Amendment mentioned the right to bear arms as being protected by it. ${ }^{139}$ Justice Alito also pointed out that in the years after the passage of the Fourteenth Amendment, members of Congress acknowledged the Fourteenth Amendment's role in applying Second Amendment protection to the states. ${ }^{140}$

\footnotetext{
131. Id. at 3026 (citing District of Columbia v. Heller, 554 U.S. 570, 576, 636 (2008)).

132. Id. at 3036 .

133. Id. (quoting Heller, 554 U.S. at 599).

134. Id. (alteration in original) (quoting Heller, 554 U.S. at 630).

135. Id. (citing Heller, 554 U.S. at 592-95).

136. See id. at 3037 (citing Heller, 554 U.S. at 598-603).

137. Id. at 3036 (quoting Washington v. Glucksberg, 521 U.S. 702, 721 (1997)).

138. See id. at 3040-41.

139. Id. at 3041 ("Senator Samuel Pomeroy described three 'indispensable' 'safeguards of liberty under our form of Government.”' (quoting ConG. GLOBE, 39th Cong., 1st Sess. 1182 (1866))).

140. Id. at 3041-42.
} 


\section{B. Justice Thomas's Concurrence}

Justice Thomas's concurrence in McDonald laid out the framework for abdicating the doctrine of substantive due process in favor of the Privileges or Immunities Clause of the Fourteenth Amendment. Before ascertaining the original meaning of the Privileges or Immunities Clause, Justice Thomas dealt with Slaughter-House and its progeny. He first cited Slaughter-House's distinction between state and federal citizenship $^{141}$ and noted Justice Miller's possible lifeboat for incorporation by his mention of the right to assemble and the privilege of the writ of habeas corpus. ${ }^{142}$ Justice Thomas then explained that any notion of incorporation in Slaughter-House disappeared three years later in Cruikshank when the Court held that the First and Second Amendments were natural rights predating the Constitution and, therefore, not privileges of United States citizenship. ${ }^{143}$ After dismissing the Court's decision in Saenz v. Roe, he began his assault on the true villain of this story-substantive due process. ${ }^{144}$

Justice Thomas argued that with the Privileges or Immunities Clause marginalized under Slaughter-House and Cruikshank, those seeking federal protection of fundamental rights had to go elsewhere in the Constitution and found the Due Process Clause of the Fourteenth Amendment. ${ }^{145}$ At first, the provision only incorporated against the States those rights that were "sufficiently "fundamental"” and "essential to the scheme of ordered liberty," but eventually the Court also enforced unenumerated rights against the States via the Due Process Clause. ${ }^{146}$ As examples, he cited three of the most infamous cases involving substantive due process-Lochner v. New York, ${ }^{147}$ Roe v. Wade, ${ }^{148}$ and

141. See id. at 3060 (Thomas, J., concurring in part and concurring in the judgment). Justice Thomas pointed out that the Slaughter-House Court held that the Privileges or Immunities Clause only protects federal citizenship and not state citizenship. Id. (citing The Slaughter-House Cases, 83 U.S. (16 Wall.) 36, 78 (1873)).

142. Id. at 3061; see supra text accompanying notes 61-70.

143. McDonald, 130 S. Ct. at 3060 (Thomas, J., concurring in part and concurring in the judgment) (citing United States v. Cruikshank, 92 U.S. 542, 551, 553 (1876)).

144. See id. at 3061-63. "The notion that a constitutional provision that guarantees only 'process' before a person is deprived of life, liberty, or property could define the substance of those rights strains credulity for even the most casual user of words.” Id. at 3062.

145. Id. at 3061 .

146. Id. at 3061-62 (quoting id. at 3046 (plurality opinion)).

147. 198 U.S. 45, 53, 64-65 (1905) (finding that a New York labor law infringed upon the freedom of contract as a "liberty of the individual protected by the [Fourteenth] Amendment").

148. 410 U.S. 113, 166-67 (1973) (finding that a Texas law prohibiting abortion violated the 
Lawrence v. Texas. ${ }^{149}$ Despite his agreement with the plurality that the Second Amendment protects a fundamental right, he lumped the plurality opinion in with Lochner, Roe, and Lawrence to demonstrate the folly of using that method of incorporation, which he considers a "legal fiction" that lacks a guiding principle. ${ }^{150}$

Justice Thomas finally had an opportunity to ascertain "the meaning of the Fourteenth Amendment agreed upon by those who ratified it."151 Reasoning that the authors of the Fourteenth Amendment would have written it to be understood by the voters, Justice Thomas explained that his real task was finding what "'ordinary citizens"” would have understood the Privileges or Immunities Clause to mean at the time of ratification. ${ }^{152}$ First, he pointed out the terms "privileges" and "immunities" had a long tradition, going back centuries in England, as being synonymous with "rights." 153 He pointed out that the public's previous understanding of their privileges and immunities as citizens of the several states provided under Article IV, Section 2 of the Constitution to further his case-privileges and immunities are only those rights " which are, in their nature, fundamental.",154 Article IV, Section 2 therefore kept States from denying traveling citizens the fundamental rights they guaranteed to their own citizens. ${ }^{155}$

But Justice Thomas still faced two huge questions of constitutional interpretation. First, he asked, "[a]re the privileges or immunities of 'citizens of the United States' recognized by $\S 1$ the same as the privileges and immunities of 'citizens in the Several States' to which Article IV, § 2 refers?"156 Justice Thomas answered that the evidence "overwhelmingly demonstrates" that the privileges and immunities protected by Section 1 included individual enumerated constitutional rights, such as the right to bear arms. ${ }^{157}$

Fourteenth Amendment's Due Process Clause)

149. 539 U.S. 558, 578-79 (2003) (finding that a Texas law prohibiting certain sexual conduct between individuals of the same sex violated the Fourteenth Amendment's Due Process Clause).

150. McDonald, $130 \mathrm{~S}$. Ct. at 3062 (Thomas, J., concurring in part and concurring in the judgment).

151. Id. at 3063 .

152. Id. (quoting District of Columbia v. Heller, 554 U.S. 570, 576-77 (2008)).

153. Id.

154. Id. at 3067 (quoting Corfield v. Coryell, 6 F. Cas. 546, 551 (C.C.E.D. Pa. 1825) (No. 3,230)).

155. Id. at 3068 .

156. Id.

157. Id. 
Drawing on a variety of sources, Justice Thomas focused primarily on the context in which the thirty-ninth Congress enacted the Fourteenth Amendment because it "illuminates what the public understood the words chosen by the draftsmen to mean." ${ }^{158}$ He pointed to a speech by the main author of the Fourteenth Amendment, Representative John Bingham, that expressly advocated that Section 1 of the Fourteenth Amendment enforced the Bill of Rights against the States. ${ }^{159}$ Representative Bingham's speech was published as a pamphlet and distributed across the country. ${ }^{160}$ The sponsor of the Amendment in the Senate, Senator Jacob Howard, made a similar argument on the Senate Floor. ${ }^{161}$ Senator Howard's speech was published and discussed in newspapers across the country. ${ }^{162}$ Justice Thomas concluded that these statements, among others, "point unambiguously toward the conclusion that the Privileges or Immunities Clause enforces at least those fundamental rights enumerated in the Constitution against the States."163

Second, Justice Thomas asked, “[d]oes §1, like Article IV, § 2, prohibit only discrimination with respect to certain rights if the State chooses to recognize them, or does it require States to recognize those rights?”164 Justice Thomas rejected the interpretation that Section 1 is merely a nondiscrimination clause, stating:

Section 1 guaranteed the rights of citizenship in the United States and in the several States without regard to race. But it was understood that liberty would be assured little protection if $\S 1$ left each State to decide which privileges or immunities of United States citizenship it would protect. ${ }^{\text {.65 }}$

The drafters, therefore, intended the Clause to establish a "minimum baseline of federal rights" for all Americans. ${ }^{166}$

Finally, Justice Thomas dealt with the fact that his analysis would effectively overturn more than a century of Supreme Court precedent

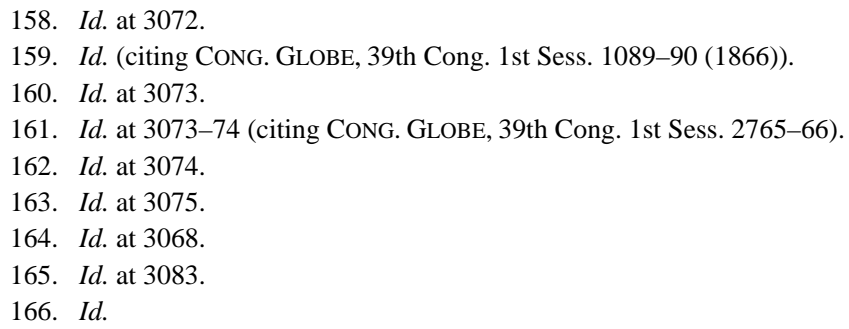


beginning with Slaughter-House and Cruikshank. ${ }^{167}$ Though Justice Thomas is certainly not the Court's most faithful guardian of stare decisis, he acknowledged its importance and longevity and recognized that his reasoning broke new ground in modern jurisprudence. ${ }^{168}$ He did not hesitate, however, to reject both the Slaughter-House definition of privileges or immunities of federal citizenship and the application of Slaughter-House in Cruikshank. ${ }^{169}$ In his view, given the historical evidence, privileges or immunities of federal and state citizenship should overlap; therefore, Slaughter-House was incorrect in that regard. ${ }^{170}$ Despite the precedent of Slaughter-House and Cruikshank-which he dismissed-Justice Thomas saw the historical evidence in favor of incorporating the Second Amendment against the States as too strong to ignore. $^{171}$

\section{DISCUSSION}

\section{A. The Plurality's Unsatisfying Discussion of Privileges or Immunities}

Justice Alito's plurality opinion was extremely disappointing for originalists who hoped to fully revive the Privileges or Immunities Clause, especially given the manner in which the Court did it-devoting only 172 words to the topic. ${ }^{172}$ Alan Gura, counsel for petitioners in McDonald, and Ilya Shapiro, Editor-in-Chief of the Cato Institute's Supreme Court Review, described the plurality's opinion as "uncharacteristically curt" and "odd" given the importance of the issue. $^{173}$

Although the plurality mentioned the Slaughter-House dissents of Justices Bradley, Field, and Swayne and admitted that "many legal scholars" dispute the Slaughter-House interpretation, ${ }^{174}$ they failed to

\footnotetext{
167. Id. at 3084 .

168. See id. at 3062-63. "I further acknowledge the importance of stare decisis to the stability of our Nation's legal system. But stare decisis is only an 'adjunct' of our duty as judges to decide by our best lights what the Constitution means. It is not 'an inexorable command.'” Id. (citations omitted) (quoting Planned Parenthood of Se. Pa. v. Casey, 505 U.S. 833, 963 (1992); Lawrence v. Texas, 539 U.S. 558, 577 (2003)).

169. See id. at $3086-88$.

170. Id. at 3087.

171. Id. at 3088.

172. Gura, Shapiro \& Blackman, supra note 8, at 178.

173. Id. at $177-78$.

174. McDonald, 130 S. Ct. at 3029-30 (plurality opinion) (gathering sources that illustrate the
} 
give any meaningful consideration to overturning Slaughter-House. Noting petitioners' inability to identify the full scope of the Privileges or Immunities Clause and lack of consensus among Slaughter-House critics on the issue, the plurality "decline[d] to disturb the Slaughter-House holding" "175 without so much as a paragraph of inquiry as to the original meaning of the Privileges or Immunities Clause itself. ${ }^{176}$

Despite acknowledging that the right to bear arms is "“deeply rooted in this Nation's history and tradition", 177 and citing many of the same sources as Justice Thomas about the understanding of Section 1 of the Fourteenth Amendment at the time it was adopted, ${ }^{178}$ the plurality refused to discuss or investigate which clause in Section 1 was intended by the authors to be used to apply the Bill of Rights to the States. ${ }^{179}$ Gura and Shapiro point out that Justice Alito cited a statement by Senator Howard that expressly stated that the Fourteenth Amendment protected the rights guaranteed by the first eight amendments ${ }^{180}$ but failed to recognize that the topic of Senator Howard's speech was not the Fourteenth Amendment in general or even Section 1-it was specifically the Privileges or Immunities Clause. ${ }^{181}$ They further point out that Justice Alito made the same mistake again when referring to a similar statement by Representative Bingham ${ }^{182}$-pointing out that Representative Bingham specifically said, “'[P]ermit me to say that the privileges or immunities of citizens of the United States, as contradistinguished from citizens of a State, are chiefly defined in the first eight amendments to the Constitution of the United States.",183

disparate viewpoints).

175. Id. at 3030-31.

176. See id. at 3028-31 (discussing early Fourteenth Amendment cases but offering no explanation of the Clause's original meaning).

177. Id. at 3036 (quoting Washington v. Glucksberg, 521 U.S. 702, 721 (1997)).

178. See id. at 3033 n.9 (citing CONG. GLOBE, 39th Cong., 1st Sess. 2765 (1866) (statement of Senator Jacob Howard)).

179. See id. at 3033 (noting simply that the Court has since embraced a selective-incorporation approach via the Due Process Clause).

180. Gura, Shapiro \& Blackman, supra note 8, at 180.

181. Id. ("As shown in the fuller quote of the same speech ... the subject of Howard's speech was the Privileges or Immunities Clause.").

182. Id. at $180-81$.

183. Id. at 181 (quoting CoNG. GLOBE, 42d Cong., 1st Sess., App. 84 (1871)). 


\section{B. Why Scalia? Why?}

Perhaps most disheartening for proponents of the Privileges or Immunities Clause, though not necessarily surprising given his joining of the majority in Saenz v. Roe, was Justice Scalia's refusal to sign on to Justice Thomas's concurrence, or at least make his own case in his concurrence for why he would not use the Clause. The esteemed Justice, who has been described as "the Court's premier [judicial] conservative, intellectual gladiator, and chief wordsmith," 184 passed on a golden opportunity to go to bat for originalism ${ }^{185}$ and help turn the tide against his arch enemy-substantive due process. ${ }^{186}$ Instead, Justice Scalia embraced his nemesis, choosing stare decisis and expediency over originalism. $^{187}$

Shockingly, Justice Scalia only devoted fifty-five words in his concurrence to the Privileges or Immunities Clause. ${ }^{188}$ He merely wrote:

I join the Court's opinion. Despite my misgivings about Substantive Due Process as an original matter, I have acquiesced in the Court's incorporation of certain guarantees in the Bill of Rights "because it is both long established and narrowly limited." This case does not require me to reconsider that view, since straightforward application of settled doctrine suffices to decide it. ${ }^{189}$

Justice Scalia wrote his separate concurring opinion only to "respond to some aspects of Justice Stevens' dissent."190 The rest of the opinion disputes Justice Stevens's claim that the living constitution method of incorporation is "more 'cautiou[s]' and respectful of proper limits on the judicial role."191

184. RING, supra note 9, at ix.

185. See Gura, Shapiro \& Blackman, supra note 8, at 187 ("Justice Scalia could have demonstrated fidelity to the judicial method he would use to attack Justice Stevens by joining Justice Thomas’s concurrence.”).

186. See id. at 182 (stating that Justice Scalia has described substantive due process as "babble," a "usurpation," and an "atrocity”).

187. See id. at 184 .

188. Id. at 182.

189. McDonald v. City of Chicago, 130 S. Ct. 3020, 3050 (Scalia, J., concurring) (citation omitted) (quoting Albright v. Oliver, 510 U.S. 266, 275 (1994) (Scalia, J., concurring)). But see Gura, Shapiro \& Blackman, supra note 8, at 182 (describing Justice Scalia's concurring opinion as "quixotic").

190. McDonald, 130 S. Ct. at 3050 (Scalia, J., concurring).

191. Id. at 3050 (alteration in original) (citing id. at 3119-20 (Stevens, J., dissenting)). 
While Justice Scalia's opinion itself does not give much insight into his thought process on the issue, his exchanges during the McDonald oral argument are somewhat telling of his reasoning. In this case, he was unusually concerned with stare decisis ${ }^{192}$ and the practicality of using substantive due process instead of overturning a century of precedent. Though he joined Justice Alito’s plurality opinion, he did not, however, seem worried about petitioners' failure to define the scope of the Privileges or Immunities Clause.

In oral arguments, Justice Scalia asked lead counsel for the petitioners, "do you think [it is] at all easier to bring the Second Amendment under the Privileges [or] Immunities Clause than it is to bring it under our established law of substantive due [process]?"193 Justice Scalia continued, "[a]nd if the answer is no, why are you asking us to overrule ... 140 years of prior law ... when you can reach your result under substantive due [process]?" ${ }^{194}$ He then referred to the petitioners' argument as "the darling of the professoriate" 195 and inquired why the petitioners would take on the heavy burden of incorporating via the Privileges or Immunities Clause and overturning Slaughter-House instead of simply using substantive due process. ${ }^{196}$ But, he did not ask any questions concerning the creation or limitation of unenumerated rights. ${ }^{197}$

Recall that Justice Scalia silently voted with the majority in Saenz, where the Court protected an unenumerated right to travel using the Privileges or Immunities Clause. ${ }^{198}$ Therefore, Justice Scalia agreed with Justice Stevens's statement that the right to travel is "firmly embedded in our jurisprudence," "s9 "so important that it is 'assertable against private interference as well as governmental action,... [and] a virtually unconditional personal right, guaranteed by the Constitution." "200 The Saenz majority believed the right to travel "has always been common

192. See RING, supra note 9, at 15 (stating that "some critics assert that while Scalia decries judicial activism, he is an activist himself because he often votes to strike down laws and overturn Court precedents," however, "when he has ignored the doctrine of stare decisis[,] . . he has done so because the Court's previous holding had no foundation in constitutional text”).

193. Transcript of Oral Argument, supra note 17, at 6.

194. Id. at 6-7.

195. Id. at 7.

196. See id.

197. See id. at 6-17.

198. Saenz v. Roe, 526 U.S. 489, 491 (1999).

199. Id. at 498 (citing United States v. Guest, 383 U.S. 745, 757 (1966)).

200. Id. (quoting Shapiro v. Thompson, 394 U.S. 618, 643 (1969) (Stewart, J., concurring)). 
ground,"201 and it relied on both Justice Miller's majority opinion and Justice Bradley's dissent in Slaughter-House as evidence. ${ }^{202}$

Justice Stevens acknowledged that he agreed with the McDonald plurality that the Privileges or Immunities Clause does not apply because "the original meaning of the Clause is not as clear as [the petitioners] suggest . . . and not nearly as clear as it would need to be to dislodge 137 years of precedent." 203 But Justice Stevens did not hesitate to invoke the Privileges or Immunities Clause in Saenz. ${ }^{204}$ It seems Justice Stevens found three major differences between Saenz and McDonald. First, Saenz did not require overturning Slaughter-House. ${ }^{205}$ Second, the scope of the right was limited and clearer in Saenz than it was in McDonald. Third, McDonald involved the Second Amendment, which is already covered under substantive due process.

\section{The Future}

1. Reviving the Privileges or Immunities Clause Without Overturning Slaughter-House

Overturning Slaughter-House is not necessarily a prerequisite to reviving the Privileges or Immunities Clause. Slaughter-House did not involve any claims under the first eight amendments, and Justice Miller's opinion did not explicitly deny incorporation of the Bill of Rights. ${ }^{206}$ The right to travel at issue in Saenz was not at issue in Slaughter-House and was only mentioned in dicta by the Court. ${ }^{207}$ While Slaughter-House is a huge hurdle, it should not necessarily preclude a continued discussion of the meaning of the Privileges or Immunities Clause. In fact, there is a strong case for reinterpreting Slaughter-House to include Bill of Rights protections. ${ }^{208}$ The current Court could do this by

201. Id. at 503.

202. Id. (citing The Slaughter-House Cases, 83 U.S. (16 Wall.) 36, 80 (1873); id. at 112-13 (Bradley, J., dissenting)).

203. McDonald v. City of Chicago, 130 S. Ct. 3020, 3089 (2010) (Stevens, J., dissenting) (footnote omitted).

204. See Saenz, 526 U.S. at 503.

205. See id. (noting the acknowledgment of the right to travel in Slaughter-House).

206. See supra notes $61-70$ and accompanying text.

207. See Slaughter-House, 83 U.S. (16 Wall.) at 77.

208. See Newsom, supra note 37, at 666 ("There is nothing in Miller's opinion... that forecloses the decidedly nontrivial notion that the Clause incorporated Bill of Rights freedoms. In fact, there is an eminently reasonable reading ... that suggests quite the opposite.”). 
distinguishing between the common law economic rights that were at issue in Slaughter-House and "core Bill of Rights freedoms"209 such as the Second Amendment protections at issue in McDonald.

\section{Defining the Scope of Federal Privileges or Immunities}

The McDonald plurality and Justice Stevens correctly note that the full scope of the Privileges or Immunities Clause is unclear, especially when it comes to unenumerated rights. This is a major question in constitutional law that should draw continued discussion. Even Justice Thomas admits that "[l]egal scholars agree on little beyond the conclusion that the Clause does not mean what the Court said it meant in 1873."210 In Saenz, however, Justices Scalia and Stevens used the Clause to invoke an unenumerated right, yet expressed no reservations about not fully defining the scope of federal privileges or immunities. ${ }^{211}$ In contrast, the McDonald petitioners did not ask for total incorporation of the Bill of Rights, nor did they ask for an unenumerated right-they merely asked the Court to enforce one right against the states, which was the individual right to keep and bear arms for self defense in the home under the Second Amendment. ${ }^{212}$ So, why then would Justices Scalia and Stevens, who disagreed over the McDonald outcome and the nature of the Second Amendment, be content using the Privileges or Immunities Clause in Saenz, but not in McDonald? The answer is, of course, substantive due process.

\section{Privileges or Immunities Dies Again?}

Justice Scalia's questions during oral argument, ${ }^{213}$ his concurrence, ${ }^{214}$ and the plurality opinion ${ }^{215}$ all show that he based his acquiescence to substantive due process on a pragmatic and realistic evaluation of the state of modern constitutional jurisprudence. After

209. Id. at 667.

210. Saenz, 526 U.S. 489, 522 n.1 (1999) (Thomas, J., dissenting) (gathering sources that illustrate the wide-ranging views).

211. See id. at 498-511 (majority opinion).

212. See McDonald v. City of Chicago, 130 S. Ct. 3020, 3028 (2010) (plurality opinion).

213. See Transcript of Oral Argument, supra note 17, at 6-11.

214. McDonald, 130 S. Ct. at 3050 (Scalia, J., concurring).

215. See id. at 3036-44 (plurality opinion) (discussing incorporation through the Due Process Clause). 
years of dissenting valiantly while the Court recognized more and more unenumerated rights, Justice Scalia has shifted his focus. Instead of expressing his "misgivings" about substantive due process and fighting the good fight, perhaps he is now using the twilight of his remarkable career on the bench to help shape the future of substantive due process jurisprudence on the Roberts Court, instead of tearing it down.

While the plurality opinion may be considered incorrect by true originalists, it is indeed a practical course of action. In the end, the Second Amendment was still enforced against the States. Justice Scalia even got the petitioners' counsel in McDonald to admit during oral argument that the tests for whether a right is fundamental under substantive due process and the Privileges or Immunities Clause are nearly identical. ${ }^{216}$ Sure, Justice Scalia may have doomed the rebirth of the Privileges or Immunities Clause before it ever occurred, but even if he had not acquiesced, it is very unlikely that the "misgivings" he has about substantive due process would have been rectified by reviving the Privileges or Immunities Clause.

\section{CONCLUSION}

Justice Thomas's concurrence, while lone and underappreciated by the other eight members of the Court, could serve as the foundation for a future Supreme Court to reconsider the meaning of the Privileges or Immunities Clause. The "privileges" and "immunities" of federal citizenship, regardless of their scope, have a long history in this country. They were certainly important enough that the authors of the Fourteenth Amendment decided to include them in Section 1-directly before the Due Process Clause. ${ }^{217}$

Even if the Privileges or Immunities Clause is forever doomed to remain "the darling of the professoriate," 218 the prerogative of defining constitutional rights, privileges, and immunities is still left to the Supreme Court under the Due Process Clause. Because the tests for determining the applicability of rights against the States under the Privileges or Immunities and Due Process Clauses are nearly identical, it is likely that originalist members of the Court will still have the framework available to limit the creation of unenumerated rights. Using

216. Transcript of Oral Argument, supra note 17, at 11.

217. See U.S. CONST. amend. XIV, § 1 .

218. Transcript of Oral Argument, supra note 17, at 7. 
the Due Process Clause is much less controversial and allows the Court to make incremental progress without drawing the controversy of overturning Slaughter-House and 138 years of precedent. Even if the Privileges or Immunities Clause remains dead, however, the Court, as well as the professoriate, should at the very least consider its original meaning and use it as a guidepost when determining what rights are fundamental under substantive due process. This may be the practical solution to remaining faithful to both stare decisis and the authors of the Fourteenth Amendment. 